\title{
Nuwere Ontwikkelings op die Gebied van die Sistematiese Teologie
}

(Lesing gehou te Pretoria, 15 Augustus 1978 en opgedra aan prof dr F J van Zyl by sy uittrede as teologiese professor op 31 Desember 1978).

B J ENGELBRECHT

\section{Die twee pole}

1.1 Die teologiese wetenskap in die algemeen, en daarmee ook die vakwetenskappe Dogmatiek en Teologiese Etiek, is by herhaling deur verskillende teoloë gedefinieer as vertaalwerk. Ook onsself het in verskillende artikels gestel dat die taak van die prediking dít is om die oeroue boodskap van die Bybel op verstaanbare wyse vir die moderne mens te bring sonder om die werklike wese van daardie boodskap skeef te trek. Die taak van die teologie (as denkdiens aan kerk en verkondiging) is dan om die boodskap van die Bybel in sy konteks suiwer te ontsyfer en om dit dan in die moderne situasie tot spreke te bring. So gesien, is daar in die prediking én in die teologie (wat kerk en prediking dien) twee pole naamlik (i) die bron van die boodskap, die Bybel én (ii) die ontvanger van die boodskap, die mens van vandag. Sommige teoloë praat van die pakket én sy ontvanger. Hulle gebruik dié beeld om tot uitdrukking te bring dat die Bybelse boodskap in oeroue vorms verpak is; dat die pakket eers "oopgemaak" moet word, herverpak en geadresseer moet word sodat dit ten minste die regte adres sal bereik. Hierdie regte adres is die moderne mens van die grootstad wie se leefwêreld dié van die telefoon, radio, televisie, motor, vliegtuig, teleskoop, elektromikroskoop, rekenaars en ander tegniese prestasiegoed is en wat radikaal verskil van die leefwêreld van die Bybelse mens.

1.2 Nou is daar gedurende die afgelope twee dekades eerstens intensiewe navorsing gedoen ten opsigte van die bron van die boodskap, dit wil sê op die gebied van die Bybelwetenskap. Dit het veral in verband gestaan met die effektiefste beginsels en metodes van Bybeluitleg en Bybelvertaling. Omdat die Woord van God die enigste bron en norm van ons geloof en lewe is, is dit duidelik dat nuwe insigte en resultate op hierdie gebied groot invloed op beide die Dogmatiek én Teologiese Etiek sal hê. Dit sal dan ook die eerste onderwerp wees wat ons breedvoeriger met mekaar sal behandel. 
1.3 Maar in hierdie selfde tyd het daar ook 'n radikale wending plaasgevind in die waardering van die ontvanger van die boodskap, die mens. Vir Karl Barth het die uitsonderlike aard van die Christelike openbaring juis daarin gelê dat dit loodreg van Bo af ingeslaan het. By die ontvanger wou Barth selfs nie eers van 'n aanknopingspunt praat nie, 'n punt wat volgens definisie selfs geen lengte, breedte of hoogte gehad het nie. Maar in die afgelope twee dekades het die horisontale dimensie en veral die mens soveel uitbreiding en waarde gekry sodat dit in baie gevalle selfs die hermeneutiese prinsiep geword het van hoe 'n mens die bron, die Skrif moet "uitlê". Binne die Sistematiese Teologie vind mens selfs uitsprake soos: "Teologie is antropologie" of: "The language of Theology is the language of politics" $(12,20)$. Hoe hierdie wending na die horisontale dimensie die Dogmatiek en Teologiese Etiek beïnvloed het, sal ons in die tweede deel van ons lesing ter sprake laat kom.

2 Die invloed van die nuwere rigtings en resultate van die Bybelwetenskappe op die Sistematiese Teologie

A Werk op die gebied van Bybelvertaling

2.A.1 Ons, in die Hervormde Kerk, het maar in die afgelope aantal jare begin besef wat die reuse omvang van die Bybelvertalingsprojekte van organisasies soos die United Bible Societies is, en stadigaan het ons bewus begin word van die groot volume en hoë kwaliteit van navorsing oor taal wat vandag agter hierdie vertalingsprojekte staan. Eugene A Nida is byvoorbeeld die United Bible Societies se "World Translations Research Co-ordinator" en Kenneth L Pike en sy kollegas werk weer op dié gebied by die Wycliffe Bible Translators. Hierdie manne is wêreldbekende taalkundiges en hulle steun weer op die linguistiese navorsing en teorië van ewe bekende taalkundiges soos Charles R Taber, Noam Chomsky, Sidney M Lamb, H A Gleason, Wallace L Chafe, Charles J Fillmore en in later tyd op James Barr en Barr se voorgangers soos die geniale Switser, Ferdinand de Saussure, en die groot Amerikaners Leonard Bloomfield en Roberts E Longacre.

2.A.2 Op die gebied van Bybelvertaling is daar dan eerstens navorsing gedoen oor die aspek van die ontsyfering van die teks van die Bybel om presies agter te kom wat daar geskryf staan. Nida noem dit die bron ("the source"). Maar dan is daar ook navorsing gedoen nie net oor die ontvangstaal (wat Nida "the receptor" noem) nie, maar ook oor die hele proses van die oorbring van die boodskap vanaf "the source" na "the receptor". Dié proses word die kommunikasieproses genoem, die proses waarin mense op die wyse van die taal kommunikeer. Dit het oa geblyk dat die kommunikasie-situasie dik- 
wels die struktuur van die taal bepaal, partymaal by die bron, die Bybel, maar veral by die ontvangspunt, die Bybelvertaling $(35,309$ v v). Ongelukkig sal ons in hierdie lesing die aspek, selfs maar kortliks, nie kan behandel nie.

2.A.3 Tradisioneel is daar in die proses van Bybelvertaling veral gewerk met:

(a) woorde en hulle betekenisse én

(b) met woorde en hulle grammatikale verband en funksie.

(i) Die betekenis en betekenis-skakering van woorde is meestal bepaal met behulp van die historiese linquistiek wat die geskiedenis van woorde (maar ook van bepaalde strukture, soos die grammatikale struktuur) in 'n bepaalde taal nagegaan het én deur die vergelykende linquistiek wat oa woorde en woordstamme binne ' $n$ bepaalde taalfamilie (soos die semitiese taalfamilie) met mekaar vergelyk en van mekaar afgelei het.

(ii) Die grammatikale model wat gebruik is, wat veral die Latynse model waarin byvoorbeeld woorde ingedeel is in selfstandige naamwoorde, byvoeglike naamwoorde, voornaamwoorde en werkwoorde (welke groep verbuigings en vervoegings het en waarby geslag - behalwe by die werkwoord - 'n rol speel), asook bywoorde, voorsetsels, voegwoorde en tussenwerpsels wat nie verbuig nie, behalwe wanneer bywoorde 'n vergelykende trap het.

(c) Hierdie tradisionele vertaalmetode het meestal ' $n$ taamlike letterlike vertaling tot gevolg gehad wat dikwels ver van die gewone gebruikstaal en nader aan die oorspronklike tale, hulle idioom en grammatikale model gestaan het én wat nie altyd duidelik vir die ontvangers was nie. Dit was dikwels ook die werkwyse van die eksegese.

2.A.4 Hoe meer "vreemde tale" bestudeer is, hoe meer is besef dat bogenoemde grammatikale model nie op alle tale van toepassing is nie en nie sondermeer vir vertalingsdoeleindes bruikbaar is nie. Ons wat Afrikaans gebruik, weet dat vervoeging en verbuiging op die Latynse en Griekse model in Afrikaans ' $n$ baie ondergeskikte rol speel; dat in Afrikaans die relatiewe posisies van woorde in 'n sin én die preposisiegebruik baie belangriker is vir korrekte taalgebruik én vir suiwer betekenis-uitdrukking.

2.A.5 Hierdie toedrag van sake het daartoe gelei dat taalkundiges in die algemeen én spesifiek op die terrein van Bybelvertaling met meer-en-meer aandag grammatikale strukture begin bestudeer het.

(a) Pike en sy medestanders het byvoorbeeld die tagmemiese model ontwerp $(40,35$ en 34,302$)$. Hulle het gewone sinne geneem en veral op die posisies van woorde gefokus en gekyk watter 
woorde die "opening", die gleuf (engels: "slot") kan vul as een woord of woordgroep weggeneem word. In 'n sin soos: die ou man het gister huis toe gegaan, word die posisie van elke woord noukeurig genoteer en alle woorde wat in hierdie posisie die plek van ' $n$ bepaalde woord in kan neem, word beskryf. In die plek van die (voor "ou man") kan byvoorbeeld " $n$, hierdie, daardie, een" kom en as dit "ou mans" was "hierdie, daardie, baie, min, party" ens., maar nie ' $n$ of een nie. Verder kan die hele woordgroep: "die ou man" vervang word met "hy". Nou kan hierdie voorbeeld "gleuwe en proppe" ("slots and fillers") tot 'n hele sisteem uitgewerk word wat sy nut getoon het in die verstaan van tekste in meer as 500 tale by die Wycliffe Bible Translators via hulle "Summer Institute of Linguistics".

(b) (i) Die bruikbaarste en invloedrykste grammatikale sisteem vir Bybelvertaling is egter die Transformasionele-Generatiewe Grammatika (TGG), Noam Chomsky (11) het dit ontwerp en hy en ander (soos Chase (10) en Fillmore wat ons vroeër genoem het) het dit uitgebrei en verfyn, terwyl Nida, (31) Taber (32) ens. dit op Bybelvertaling toegepas het. In Suid-Afrika was die eerste eksponente daarvan F A Ponelis (41) van Unisa, M C J van Rensburg van U.P., (54) J P Louw van U.P. (25) terwyl ook ds A G van Aarde (51) in 'n onlangse artikel waardering daarvoor toon.

(ii) Die TGG verontagsaam nie die verskillende lae waarin taal voorkom en fungeer nie, soos die semantiese, leksikale, sintaktiese, morfologiese en fonologiese lae nie. Maar die TGG het die begrip struktuur gebruik om onderskeid te maak tussen die bolaag van die taal ("the surface structure") én die grondlaag ("base", "deep structure" of "kernel structure"). Die bolaag van die taal is dié sinne, soms lank en ingewikkeld, wat mense elke dag gebruik om mee te kommunikeer. Maar hierdie, soms ingewikkelde en nie altyd duidelike bolaag, is opgebou uit 'n klein aantal elementêre kern-strukture wat gesamentlik hierdie dieptestruktuur, hierdie grondlaag van die taal vorm. Aanvanklik is gestel: Die mens is so geskape $(37,308)$ dat hy alles waaroor hy praat, basies net in vyf eenvoudige "soorte" kernsinne (ook kola genoem) kan uitdruk. Hoewel die mens dus in hierdie basiese kernsinne van die dieptestruktuur alles kan sê, sê hy dit egter gewoonlik nie so nie, maar praat hy meestal op die ingewikkelder sinsboumanier van die bolaag van die taal. Dit gebeur deur die proses van transformasie wat uit hierdie eenvoudiger kerns van die grondlaag uitgebreider bolaagstrukture, ingewikkelder sinne vir alledaagse gebruik opbou. So kan sinne in die ne- 
gatiewe vorm, in die passiewe vorm, in die wensvorm ens., almal uit 'n eenvoudige aktiewe stellende positiewe kernsin soos "die man gee" opgebou word. Nida noem hierdie proses van transformasie "one of the very important discoveries which linguists have made about language" $(33,229)$, terwyl hy van die woord wat ons al gebruik het, naamlik "struktuur", sê: "Perhaps the most important insight which has come from the study of languisties is the concept of structure..." $(33,227)$.

(iii) Aanvanklik het die TGG-mense gesê dat die mens só geskape is dat sy brein 'n paar eenvoudige soorte kernsinne genereer wat in alle tale voorkom en wat hy by wyse van transformasie in elke taal op 'n eie manier in 'n bolaag kan verander sodat hy alles kan sê wat hy wil sê. Die dieptestruktuur, die onderlaag is dus gesien as primêr sintakties, as iets wat primer met sinne en sinsbou te doen het. Maar hulle het ál meer-en-meer begin stel dat nie net kernsinne in die onderlaag gesetel is nie, maar ook die betekenis van sinne. Die betekenisleer word in die linguistiek die semantiek genoem. Die TGG het dus al meer-en-meer begin stel dat die dieptestruktuur eintlik die semantiese struktuur self is, die betekenisstruktuur self. Die genoemde Chafe $(34,305)$ sien die saak selfs só, dat die grondlaag drie strukture het. Die semantiese, dié een wat met die betekenis te doen het, is outonoom. As dit in woorde omgesit word ("lexicalized") dan kan dit uitgestippel word as die sintaktiese struktuur (die genoemde struktuur van kernsinne) wat op sy beurt weer uitgestippel kan word as klanke, as die fonologiese struktuur. Fillmore weer het die sogenaamde "case grammar" ontwerp. Hy sien die werkwoord as die kern waarom daar soos die planete om die son sekere basiese satalietwoorde wentel. Hierdie satalietwoorde is woorde wat basiese denk-en spreek-wyses oor die werklikheid uitdruk, want hulle gee antwoord op oa die volgende basiese vrae in verband met ons denkende en sprekende omgang met die werklikheid, naamlik: Wie of wat is die dader? Wat is die mikpunt (of doel)? Wat word gedoen of wat gebeur? Waar gebeur dit en wanneer? Waarmee word dit gedoen? $(34,304,305)$.

(iv) Verdere TGG-studie het gelei tot die ontdekking van die sogenaamde "language universals" $(33,231)$ die algemene taalkonstantes wat in alle tale, hoe primitief ookal teenwoordig is. Die eerste is dat elke taal logiese verbande uitdruk soos die relasie tussen oorsaak en gevolg. Oa druk ons dit in Afrikaans uit met: "Hy het dit gedoen, dus (of: 
daarom) moet hy nou ly". Alle tale moet tyds-verbande kan uitdruk. Ons doen dit deur oa woorde soos toe, daarna, gister, lankal, wanneer, "het ge-", "sal" en baie meer te gebruik. Verder elke taal moet ruimtelike verbande (hier, daar, oorkant, duskant ens.) en modale verbande soos die onderskeid tussen potensialiteit en aktualiteit; tussen stellings, vrae, bevele, versoeke ens. taalkundig uit te druk. Verder besit elke taal die vermoë om tussen die vier basiese kategorië om betekenis uit te druk, te onderskei naamlik objekte, gebeure, abstraksies en verhoudings (relasies). En as die taal nou vanuit hierdie grondlaag na die bolaag transformeer, dan neem ook die eenhede van die bolaag, soos redevoeringe gewoonlik een van drie basiese strukture aan, naamlik vertelling, uiteensetting en dialoog $(33,232)$.

(v) Wat in hierdie verband nou van betekenis is vir die teologie en spesifiek vir Bybelvertaling, is dat al die ingewikkelde sinne van die bolaag in die spreek- en skryftaal, getransformeer is uit ' $n$ klein aantal bekende duidelik gedefinieerde semantiese en sintaktiese kern-eenhede. Alreeds in 1964 het Nida (31) en in 1969 Nida en Taber (32) in hierdie verband ' $n$ prosedure van Bybelvertaling opgestel wat deur vertalers van die United Bible Societies-groep en dus ook deur ons eie Bybelvertalers gebruik word. Dié prosedure behels dat elke afgeronde volsin van die bolaag geneem word, dat dit dan opgebreek word in die sintaktiese én semantiese kern-eenhede van die onderlaag deur byvoorbeeld van woorde of woordgroepe te vra: Dui dit 'n objek, 'n gebeure, ' $n$ abstraksie of 'n relasie aan? ens. So word dan met behulp van 'n klein aantal maklik-hanteerbare kern-eenhede en hulle onderlinge relasies, die betekenis van die volsinne bepaal. Die woorde en taalkundige verbande (soos die grammatika) van die brontaal het dus gehelp om die betekenis van die sin te bepaal. Maar nou word nie die woorde, woordorde en grammatikale verbande van die brontaal in die ontvangstaal vertaal nie daar word gevra: hoe gee ek hierdie betekenis die suiwerste weer in die ontvangstaal? Die rede waarom nie die woorde, woordorde ens. van die brontaal in die ontvangstaal vertaal word nie, maar dat die betekenis wat die brontaal weergegee het vertaal word, is dat elke taal op 'n eie wyse en dikwels met ander woorde 'n sekere betekenis vanuit die grondlaag na die bolaag transformeer. Dikwels sal by vertaling van ' $n$ sin nie één woordpaar (wat gewoonlik in die brontaal én in die ontvangstaal as van gelyke betekenis geld) gebruik word nie, en tog sal die sin in die 
ontvangstaal presies die betekenis weergee wat in die brontaal geleë was. Dit spreek vanself dat die beweging vanaf die bolaag na die grondlaag en terug nie net in die dekoderingsproses (die ontsyferingsproses by die brontaal) sal plaasvind nie, maar ook by die enkoderingsproses by die ontvangstaal.

(vi) Die tyd ontbreek om aan te toon hoedat, behalwe bogenoemde sake, ook ander ingewikkelde sake soos die verskillende tipes van kommunikasie (wat oa deur die kommunikasie-situasie en deur die saak van "feedback" bepaal word) én sake soos redevoering-tipes, taalvlakke (soos die konsultatiewe, formele, informele, intieme en gevriesde vlak), die sosio-ekonomiese faktor se invloed op taal esm, ' $n$ rol by vertaling speel, beide by in dekodifikasie- en die enkodifikasie-proses.

(vii) Die gevolg van hierdie aspek van taalstudie, is dat ons nou verskillende dinamiese Bybelvertalings (gedeeltelik ook alreeds in Afrikaans) en eksegesehandboeke het wat op die grondige betekenisbepaling van sinne berus. Dit is duidelik dat hierdie vertalings en eksegese nie net vir die geestelike lewe van ons kerkmense wat die Bybel lees en vir die prediking van betekenis is nie, maar ook vir Dogmatiek en Teologiese Etiek in hulle Skrifberoep.

(viii) Maar voordat ons nou meer spesifiek die invloed van hierdie nuwe wending in Bybelvertaling en Bybeluitleg vir die Sistematiese Teologie aantoon, wil ons eers op 'n ander verwante rigting wys wat veral gevolge op die eksegese gehad het en het. Ons noem die rigting, die rigting van:

\section{B. Hermogenes, de Saussure, Bloomfield, Longacre en Barr}

2.B.1 Plato sny in sy dialoog Kratulos $(34,301)$ die tema van die verhouding van woorde en hulle betekenis aan. Hermogenes stel dat woorde slegs per afspraak sekere dinge aandui. 'n Mens sou, om 'n sekere ding aan te dui, ook' $n$ ander woord kon gebruik het. Kratulos meen weer dat woorde en dinge wesenlik aan mekaar verbonde is en dat woorde spesifieke betekenis het.

2.B.2 (a) Wilhelm von Humboldt $(1767-1835)(48,307)$ het gesê dat woorde eintlik die manier is waarop die mens vorm gee aan sy ervaring van die werklikheid, waarmee hy die veelheid van hierdie ervaring saambind en orde daarin skep. Trouens, taal is ' $n$ aktiwiteit, dit doen iets (55,67 en 84). Von Humboldt stel: "die mens leef met die wêreld rondom hom ... uitsluitlik soos die taal dit aan hom bied." Omdat elke volk 'n ander taal praat, en die 
taal die ervaring van die werklikheid vorm, daarom bied elke taal aan elke volk 'n eiesoortige interpretasie van die werklikheid, 'n eie wêreldbeeld. Woorde is as't ware brokstukkies betekenis en wêreldbeskouing.

(b) Weisgerber (gebore 1899) het oa gestel dat die taal met sy betekenisvelde as't ware vir sy gebruikers dink en dat indrukke en ervarings tot ons kom, gefiltreer deur die struktuursif van die taal; gesien en gevorm en soms skeefgetrek deur die bril van die taal.

(c) In die VSA het hierdie gedagtes oor taal gelei tot die Sapir-Whorf hipotese wat beweer dat elke taal sy eie logika het en as't ware die denke van sy gebruikers in sekere vorms en kanale druk. Daarom kan 'n spreker nie in elke taal sê wat hy wil nie. Verskillende tale dwing die gebruikers daarvan om die werklikheid op verskillende maniere te ervaar, te beskou en te sê.

(d) Hierteenoor het geleerdes soos Lenneberg $(48,309)$ en Longacre (23) stelling ingeneem en beklemtoon dat woorde nie stukkies wêreldbeskouing of flentertiies kennis is nie. Woorde het nie op hulleself genome 'n algemene en vaste betekenis nie. Hulle betekenis word altyd bepaal en gewysig deur die konteks waarin hulle voorkom. Ons het nie 'n woord vir elke ding in die wêreld nie, veral nie vir elke gebeurtenis, verhouding of abstraksie nie. Sulke gebeurtenisse moet beskryf word. Dit kan alleen gebeur omdat daar 'n eindige aantal woorde en aantal sinsbou-reëls is om die werklikheid wat oneindig omvangryker en oneindig ingewikkelder en genuanseerder as woorde is, te beskryf $(33,230,48$ en 305$)$.

2.B.3 (a) Dit is hier waar James Barr met sy twee epogmakende studies, The Semantics of Biblical Language (1961) (23) én Biblical Words for Time (1962) (32) aansluit. Die hooftema van hierdie studies is die verband tussen:

(i) denke (betekenis) en

(ii) taal.

Barr is sterk krities ingestel veral teenoor mense soos Boman en Kittel wat op die patroon van Von Humboldt byvoorbeeld meen dat die spesifieke taalkundige strukture van Grieks en Hebreeus uit spesifieke Griekse en Hebreeuse maniere van dink voortspruit (óf dat die Griekse en Hebreeuse taal hierdie maniere van dink voortbring).

(b) Hierteenoor lê Barr eerstens bloot wat hy "the root fallacy" noem. 'n Woord het nie (soos dié gronddwaling dink) 'n konstante grondbetekenis nie, maar is gewoonlik polisemies, dit wil sê het ' $n$ vae of dubbelsinnige betekenis. Buitendien kom grammatikale strukture nie noodwendig ooreen met denkstrukture nie; die verhouding tussen 'n selfstandige naamwoord en werk- 
woord is nie altyd die van "ding" en "werking" nie, esm. Die sintaktiese konteks, die konteks van sinsbou speel 'n beslissende rol om betekenisse van woorde definitiewer te omlyn en te bepaal (bv Hy het / darem // vir jou ///'n mooi bok //// geskiet /////). Daarom kan ons nie (soos bv Nygren en seker ook baie van ons in die teologie gedoen het) sê dat bepaalde woorde vas aan bepaalde begrippe gekoppel is nie, soos bv dat eraoo altyd erotiese liefde, phileoo altyd vriendskap en agapaoo altyd goddelike liefde uitdruk nie. En veral kan ons nie die huidige betekenis van woorde bepaal deur etimologies te werk te gaan nie, dit wil sê deur die geskiedenis van woorde na te speur nie. Die historiese taalkunde wat diakronies te werk gaan, het wel vir wyer verband sy plek, maar woorde se betekenisse moet sinkronies bepaal word, dws uit hulle huidige kontekstuele verband.

(c) Barr was daarvan oortuig dat "Biblical theology was generalizing too broadly on the basis of scattered linquistic facts and had no contact with the semantic methods of general linquistics" soos Tängberg dit opsom $(48,303,304)$. Sy begeerte was "to increase the degree of precision in the description of linguistic material of the Bible." $(48,304)$. Daardeur het hy, soos hyself sê: "a better way to approach biblical language in its relation to theology", aangetoon (2). Tängberg sê in die lig hiervan dat egte Bybelse teologie "must concentrate on carefully interpreting the sentence and still lager discourse units that are able to convey theological information" $(48,304)$. Moderner linguistici meen dat die perikoop miskien die kleinste kontekstuele eenheid is om werklik relevante teologiese informasie oor te dra (51,47-48).

(d) Ons het baie belangrike sake by Barr, soos die saak van "linguistic field" of "semantic field" en hulle draagkrag vir die teologie, hier nie nagegaan nie. Ook het ons nie die tegnieke nagegaan hoedat eenhede soos die kolon, perikope en redevoeringe asook hulle skopusse en fokuspunte op objektiewe wetenskaplike kontroleerbare wyse bepaal kan word. Dit is oa deur dr Loader in die Hervormde Teologiese Studies, Jrg 34 afl 1 en 2 gedoen en het hy dit ook in verband met ander metodes gebring $(24,3 \mathrm{v} v)$. Want, as gestel word dat egte betekenis net uit kleiner of grotere kontekstuele verband bepaal kan word, spreek dit vanself dat al die elemente van so 'n konteks asook hulle onderlinge verband én die dekoderingsmetode op wetenskaplike manier gedefinieer en beskryf moet word. Van Bloomfield is gesê dat sy "greatest contribution to the study of language was to make a science of it" $(55,88)$. Waterman sê dat Bloomfield "was vitally interested in meaning" en het gestreef na "definitions that were scientifically verifiable and controllable" $(55,96)$. Dit geld mi sterk vir die taalstudie rondom Barr en die praktiese implementering daarvan. 
2.B.4 (a) Wie die tradisionele wyse van Skrifberoep in die Sistematiese Teologie ken, sal die groot gevolge van hierdie nuwe wendings in Bybelwetenskap vir die Sistematiese Teologie onmiddellik besef. Tradisioneel was die verwysingsmateriaal en bewysmateriaal van die Sistematiese Teologie kleiner eenhede, veral genommerde teksverse waarin of 'n woord, 'n uitdrukking, 'n sinsnede én dikwels die volle sin funksioneel was. In die Doopformulier byvoorbeeld, word Genesis 17:17 aangehaal wat stel dat die verbond met Abraham ook sy nageslag insluit. Handelinge 2:39 handel oor die vervulling van Jesus se belofte dat die gelowiges die Heilige Gees sal ontvang. Die vraag is nou: kan ons op grond van die verwysing daarna dat die belofte van die vervulling met die Heilige Gees ook vir die nageslag geld, dit in verband met Genesis 17 bring omdat albei oor die nageslag praat, en kan ons op grond daarvan sommer die belofte in verband met die Gees met die verbondsbeloftes identifiseer? Laat ek dit duidelik stel: Uit die studie van perikope in dié verband staan die onlosmaaklike verband van doop (en veral kinderdoop) én verbond vir my vas. Die vraag is net: Is ' $n$ beroep op Handelinge 2:39 in dié verband vandag nog wetenskaplik verantwoord?

(b) Natuurlik het hierdie allernuutste metodes van Skrifuitleg, wat in sy metodepluralisme ook vroeëre wetenskaplike eksegetiese metodes in ' $n$ bepaalde volgorde laat meespreek $(24,3 \mathrm{v} v)$ nie sommer oornag inslag in alle sistematiese teologie gekry het nie. Heel selde word dit in die Sistematiese Teologie met volle konsekwensie toegepas en by die sogenaamde taalkundige of hermeneutiese rigtings in die dogmatiek word dit dikwels gekruis met die filosofiese rigting van die sogenaamde "linquistic analysis" waarvan byvoorbeeld A J Ayer en G Ryle in die Eengelssprekende wêreld groot eksponente is. Volgens hulle is alleen sulke uitsprake sinvol wat empiries geverifieer kan word. Ayer sê in navolging van Wittgenstein se Tractatus oa "The theist, like the moralist, may believe that his experiences are cognitive experiences, but unless he can formulate his "knowledge" in propositions that are empirically verifiable, we may be sure that he is deceiving himself" $(1,35)$. Dit beteken dat alle metafisiese, etiese en teologiese uitsprake geen faktiese betekenis het nie.

(c) Maar teoloë soos Ian T Ramsay in sy boeke Religious Language. An Empirical Placing of Theological Phrases (New York 1963) en Models and Mystery (London 1964) sluit aan by Wittgenstein se Philosophische Untersuchungen en sê dat teologiese en etiese uitsprake 'n eie logika het en tog sinvolle modelle van spreke kan uitmaak. Genoemde twee werke is dan ook inderdaad klassieke 
voorbeelde van streng wetenskaplike metodiese analise van die religieuse taal, veral op die gebied van die Dogmatiek.

(d) ' $n$ Derglike werk wat baie opspraak verwek het maar wat tog in ' $n$ ander rigting as Ramsay gaan en die verifikasiebeginsel vir die Dogmatiek eskatologiese waarmaking sien, is: Paul van Buren, The Secular Meaning of the Gospel based on an analysis of its Language" (1963).

(e) Een van die nuutste werke in hierdie verband wat hom veral op die taalanalise van die dogmatiese spraakgebruik in die werke van Althaus, Barth, Brunner, Elert, Fritzche, Grass, Ott, Pannenberg, Schäfer, Thielicke en Tr:llhaas toespits, is: Anders Jeffner, Kriterien Christlicher Glaubenslehre, Uppsala 1976. In sy analise van dogmatiese uitsprake maak Jeffner op 'n klein skaal van sekere simbole en hulle kombinasies gebruik. Hy noem 'n geloofsleer' $n$ versameling uitsprake wat hy met die simbool $\mathrm{M}$ aandui (versameling is in Duits Menge) en wat aan drie eienskappe moet voldoen naamlik dat hulle:

(i) 'n Christelike geloofsoortuiging uitdruk;

(ii) dat hulle in die tyd en kultuursituasie waarin hulle opgestel word die beste manier is om die betrokke geloofsoortuiging uit te druk én

(iii) dat hulle ' $n$ intellektueel-aanvaarbare beskouing uitdruk.

Binne hierdie versameling $M$ tree dan 'n hele aantal geloufsleeruitsprake op wat Jeffner "G - Sätze" noem $(17,16-17)$ en wat aan verskillende semantiese kategorië behoort. Die res van Jeffner se boek in die opstelling van verskillende kriteria (indirekte kriteria, ervaringskriteria, wetenskapskriteria en logiese kriteria) waaraan sinne moet voldoen om egte G-sinne te wees. Dit word uitvoerig aan die hand van genoemde dogmatiese werke geillustreer. Belangrik is die diskussie rondom die Skrifbewys $(17,34)$ en die vraag na die aard en geldigheid van geloofsafhanklike kriteria dws die oortuiging: "Bibelkriterien in der Theologie kan nur der anwenden, der das Wort Gottes in Glauben annimmt" $(17,21)$ (Sien ook 26).

(f) Maar nie alle sistematiese teoloë het die metodepluralisme waarvan dr Loader praat, gekruis met filosofiese metodes soos dié van die analitiese filosofie nie. Só het daar in 1967 'n studie van prof John Knox, The Humanity and Divinity of Christ (Cambridge Univ Press) verskyn wat slegs met eksegetiese tegnieke die probleem en patroon van die Christologie in die Bybel en kerkleer wil nagaan. Hy meen dat ' $n$ mens nie die Nuwe Testamentiese getuienis verwring as jy stel dat die oer-Christene "most surely remembered the man Jesus" and most surely knews Him as "the heavenly Lord" $(20, v i i i)$, en dat die probleem van die verhouding van Jesus se menslikheid én sy Goddelikheid vanaf die be- 
gin teenwoordig was. Knox wil dan 'n poging aanwend "to suggest and defend the structure of New Testament christology as a whole, a way to see the pattern of its development" $(20, x)$. Knox analiseer nou eers die groter eenhede van christologiese uitsprake sinkronies en dateer dié eenhede daarna. Die merkwaardige is dat hy in die Nuwe Testament dan drie opeenvolgende modelle van Christologiese getuienis en denke kry $(20,1 \mathrm{v} v)$. Die oorspronklikste model is die adoptiaanse model wat ons die begin van Handelinge kry. Dit beteken: God het die mens Jesus tot God en Heer gemaak (as sy Seun aangeneem) by sy opstanding. Die tweede model is die kenotiese model wat ontstaan het toe die kerk van die Joodse milieu weggebreek het en oor die opstanding en na-opstanding-status van Jesus nagedink het. Die kenotiese model is presies die teenoorgestelde van die adoptiaanse model: Hy wat pre-eksistent ewiglik as God bestaan het, het Homself ontledig en nederige mens geword, soos oa in Filippense 2:5 v v gestel word. Die genoemde twee modelle het volgens Knox net ' $n$ kort afsonderlike leeftyd gehad en is later oorheers deur die docetiese model wat gestel het dat die menslikheid van Jesus slegs 'n tydelike kleed was wat $\mathrm{Hy}$, die ewige God, gedra het tydens sy aardse omwandeling en daarna uitgetrek het.

Ek gaan hier nie verder daarop in hoedat Knox die hele aangeleentheid verder uitwerk nie. Wat wel duidelik word, is dat hierdie werkwyse waar elke model op sinkroniese wyse literêr noukeurig bepaal is, die hele saak van die Skrif as norm in die Christologie geweldig problematiseer omdat ons nou nie één normatiewe Bybelse Christologie het nie. Indien die docetiese model 'n Bybelse model is, dan kan die kerk dit tog nie as dwaalleer afwys nie? (Sien ook 15 wat onderskei tussen die verkerklikte berig van die redaktor van Matteus-evangelie en die oorspronklike bedoeling van Jesus. Sodoende maak hy die gesag van die Skrif en die Skrifberoep uiters problematies.)

(g) 'n Sistematiese teoloog wat sterk op die struktuur-analitiese metode van Bybeleksegese steun, is David Tracy, Blessed Rage for order: The new pluralism in Theology, The Seabury Press, New York 1975. Een saak oorheers die hele werk en dit is dat teologie niks minder nie as byvoorbeeld geskiedenis, fisika en skeikundè objektief wetenskaplik moet wees. Dit beteken dat alle Christene "must re-examine and clarify their conceptions of divine reality" en dit kan alleen deur tekstuele struktuuranalise gebeur. In die Christologie het dit egter tot gevolg dat kritici soos Gary J Dorrien van Princeton Theological Seminary gestel het dat "the subjects that are discussed are artificially divested of their historical meanings, so that their discussion is limited to the analysis of 
"texts", the "Christian fact", or Christological myths instead of Scriptures, tradition, gospel, or the reality of Jesus".

(h) Ook Jean Carmiynac beweeg in sy Recherches sur le 'Notre Pére (Ed Letouzey et Ané, Paris 1969) in dié rigting. Op bl. 6 lees ons in dié verband die volgende volsinne:

"Pourque ces "recherches" soient aussi scientifiques que possible, trés large a été faite la part de philologie. Puisqu' une bonne theologie suppose une bonne exégèse et qu'une bonne exégèse suppose une bonne philologie; la solidité des bases philologiques est la garantie indispensable desapercus exegetiques et theologiques" (Sien dr R ten Kate, Geef ons heden ons dagelijks brood in: Ned Theol Tijdschrift, 32, 2, April 1978, bl 125 vv).

(i) Miskien is die teoloog wat die meeste erns gemaak het van die pluralisme van eksegetiese metodes ten opsigte van die Christologie, die roomskatolieke dogmaticus van Nijmegen, Edward Schillebeekckx in sy twee werke: Jesus, het verhaal van de Levende, Uitg $\mathrm{H}$ Nelissen, Bloemendaal, 1974 van — bladsye én Gerechtigheid en liefde. Genade en bevrijding by dieselfde uitgewers 1977 van 904 bladsye.

Aangesien ds G Velthuisen hieroor vir sy D D-proefskrif onder my werk, lewer ek hieroor nie verder kommentaar nie, behalwe deur te stel dat Schillebeeckx tot verrassende resultate kom waarvan die dogmatiek definitief kennis sal moet neem.

(j) Die metodepluralisme het ook sy invloed op die Christelike Etiek gehad. In 1976 het daar in dié verband 'n mooi voorbeeld verskyn deur Bruce C Birch ('n eksegeet) en Larry L Rasmussen ('n sistematikus) naamlik Bible and Ethics in Christian Life (Augsburg Publishing House, Minneapolis 1976). Die boek wys op die frustrasie van vakmanne in die Ou- en Nuwe Testamentiese Wetenskap wat in verband met die toepassing van Skrifgegewens in dié konteks dikwels gemanipuleer word; dat wel na tekste verwys word, maar dat die werklike wetenskaplike eksegese daarvan weinig verskil sal maak aan die etiese stellings en riglyne. Aan die ander kant voel die sistematici dat genoemde vakmanne wel super-gespesialiseerde historici, taal- en letterkundiges is maar heel weinig oog het vir die praktyk, vir die brandende etiese vrae van ons dag. Daarom is samewerking tussen die vakmanne dringend noodsaaklik. In hierdie twee vakmanne se soeke na 'n oplossing van die probleem om op werklik wetenskaplik-verantwoorde wyse Die Bybel en die Teologiese Etiek staan die metodologiese vraagstuk prominent voorop en hulle gee noukeurige aandag aan die worsteling van hedendaagse vakmanne uit beide die sistematiese teologie en vakmanne uit die eksegetiese en Bybels-teologiese rigting in verband met dié sentrale probleem. Uiteindelik stel hulle dat daar twee basiese ele- 
mente in die teologiese etiek is nl. "the ethics of doing" waarin die spesifieke voorskrif 'n belangrike rol speel en "the ethics of being" dit wil sê die vorming van die gelowige mens wat soos die goeie boom goeie vrugte sal dra. In die lig van die moderne eksegese het die saak van spesifieke voorskrifte wat dikwels losstaande van mekaar fungeer, problematies geword. Daarom stel hulle: "the most effective and crucial impact of the bible in Christian ethics is that of shaping the moral identity of the Christian and of the church" $(8,104)$. So kry die hele Bybelse boodskap en nie alleen (en dikwels veral nie) die sogenaamde etiese voorskrif-gedeeltes van die Bybel betekenis vir die lewe van die gelowiges en sy etiese besluitneming. Dié gedagtes word nie net deur die eksegese gesteun nie, maar ook deur die teologie soos die holistiese benadering van die Bybel deur Brevard Childs. (Sien verder 5 . Bennett sien die Bybelse aard van die Christelike Etiek daarin dat ons wel die Bybel moet lees "for general perspective rather than for prescriptive specificities". Buitendien moet ons dan ook nog sterk reken met die afstand tussen die tyd en omstandighede van die Bybel en ons situasie.)

(k) Ook die boek van Stanley Hauerwas, Character of Christian Life, Trinity Univ Press, San Antonio 1975 beweeg in dié rigting. Hy sê dat "the metaphor of command" in die lig van die moderne eksegetiese metodes problematies geword het, en hy pleit vir 'n disposisionele etiek soos dié van Luther en Calvyn waarin die gesindheid van die hart (en dan veral die "geloof", maar óók "regverdigmaking", "bekering" en "heiligmaking" die beslissende rol speel). Hierdie etiek praat in terme van "the metaphor of character" en stel dat die hele Bybel die geloof vorm en dat dade ("actions") alleen betekenis het indien dit uit die geloof voortvloei.

3 Die invloed van die rol wat die moderne mens in die beskouings van die sistematiese teologie speel vir die karakter van die sistematiese teologie vandag.

A Oor hierdie aspek het ons alreeds vroeër uitvoerig gepubliseer en daarom kan ons in hierdie deel van die uiteensetting baie korter skryf. Ons verwys na die volgende drie artikels:

(a) Hedendaagse Krisispunte in die teologie, in Hervormde Teologiese Studies, jrg 23, afl 1, bl 5-23.

(b) Die antwoord en taak van die Kerk ten opsigte van sekularisasie, in Hervormde Teologiese Studies, jrg 24, afl 3, bl 142-154 én

(c) Die Teologie van die Hoop en die teologie van die revolusie in Die Bybel en die moderne mens, SA Akademie 1974, bl 39-51. Verder 
nuttige werke in dié verband is dr J Sperna Weiland se Orientatie van 1966 sy Voortgezette Orientatie (Baarn 1971) dr J H Koekemoer, Die Christologie van die Nuwe Teologie. 'n Interpretasieprobleem 1972 en Allistair Kee, The Way of Transcendence.

B (a) Die basiese uitgangspunt van byna alle boeke wat as Nuwe Teologie beskryf kan word, is dat die ou wêreldbeeld vir die moderne mens onverstaanbaar en (in elk geval) onaanvaarbaar is. Daarom moet die Bybelse boodskap én die interpretasie daarvan in die Dogmatiek (tot onlangs), herinterpreteer en hervertaal word in die taal van die leef-en denkwêreld van die moderne mens.

(b) Die wesenlike struktuur van die sogenaamde ou wêreldbeeld is volgens die Nuwe Teologie dat dit hierdie wêreld, die mens (sy aard, taak en verantwoordelikheid) en die geskiedenis nie in terme van hulleself sien, verstaan en beleef nie, maar in terme van' $n$ ander wêreld naamlik in terme van die wêreld van God en die godsdiens. Vra ons na die oorsprong en bou van alles, dan word in terme van die ou wêreldbeeld gesê: God is die alwyse Skepper. Vra ons na die oorsprong van die bose dan word na die Satan en die demoniese magte verwys. Vra ons na die voortbestaan en verloop van alles (en spesifiek na die geskiedenis van die individu, volke en nasies) dan kom die antwoord: God is die onderhouer en beskikker van alles; Hy lei die geskiedenis. Vra ons na die sin en bestemming van die lewe en geskiedenis dan kom die antwoord: Deur die versoening in Jesus Christus en die werk van die Heilige Gees bestaan die sin en bestemming van die lewe en geskiedenis daarin dat daar vir die gelowiges 'n ewige lewe in heerlikheid in die hemel wag. ... Hieruit is die struktuur van die sogenaamde ou wêreldbeeld duidelik: $\mathrm{Na} B o$ word hierdie wêreld uitgebrei deur God en die engele; deur Satan en die Bose en deur die hemel. Na die toekoms word dit uitgebrei deur die ewige lewe en heerlikheid. Hierdie Bo-wêreld en eind-tyd bestaan volgens die ou wêreldbeeld werklik en bepaal die oorsprong, verloop, sin en eindbestemming van hierdie wêreld en geskiedenis. Omdat die daarginds en die eens" van die hiernamaals oneindig belangriker is as die hier- en-die-nou van die geskiedenis, word die historiese taak en verantwoordelikheid van die mens om te stry vir 'n beter, mensliker, regverdiger orde vanuit die ou wêreldbeeld dikwels versaak; die bestaande orde en strukture (wat bestaande belange beskerm) word gesanksioneer en deur die troos van 'n beter hiernamaals aan te bied, word gesê dat diegene wat lyding en onreg ervaar, dit maar moet verduur, want eenmaal sal almal gelyk wees en alles sal dan vir altyd mooi en heerlik wees. Soos God en die Bo-wêreld vroeër, toe die wetenskap nog nie ontwikkel was nie, gebruik is 
om natuurverskynsels te verklaar, word God en die Bo-wêreld vandag nog gebruik om die lewensraaisels te verklaar en word die hiernamaals gebruik om die stryd vir 'n beter bedeling hier op aarde te verlam.

(c) Die denk- en leefwêreld van die moderne, wetenskaplikgevormde mens is egter dié van die vaste, kontroleerbare feite én die streng logiese afleiding en samehang. "Hierdie mens glo net dit wat op vaste ervaarbare feite berus (by voorkeur herhaalbare, bewysbare, verifieerbare feite) én wat op logies-samehangende (en dus kontroleerbare) wyse geïnterpreteer is." Ayer sê: “Egte wetenskaplik-aanvaarbare" kennis is "alleen proposisies wat hulle empiries laat verifieer en bygevolg is religieuse kennis of ervaring slegs bron vir die psigiater". Biskop Pike sê: "Science, technology, affluence and secularism have eased God out of the cosmos, obliterated the supernatural dimension of life. An omniscient, omnipotent Greator is not empirically justified by the data" $(14,40)$. Sekularisasie beteken volgens Charles West dat alle lewensterreine van dink en doen onttrek is aan die gesag van die religie, van die bo-natuurlike wêreld en dat dit verstaan en beleef word in terme van wat hulleself is.

(d) Maar al is die dinge waaraan die ou wêreldbeeld glo, nie werklik nie; hulle het wel betekenis: hulle is mitiese, religieuse, metafisiese, supernaturalistiese geloofssimbole en beeldspraak wat vir die gesekulariseerde moderne mens tog ' $n$ boodskap van betekenis het. Die betekenis kan filosofies wees: volgens Tillich kan hulle die mens help in sy soeke na die laaste werklikheid, die grond van sy bestaan, die nuwe syn; by Bultmann gee hulle op mitologiese wyse antwoord op die fundamentele vrae oor wat ware eksistensie is $(12,16)$. Maar meestal is die betekenis van hierdie mitiese, religieuse, metafisiese geloofssimbole daarin geleë dat hulle antwoord gee op sosiaal-etiese vrae van hierdie wêreld in hierdie tyd $(12,9$ en $18 ; 14,42$ vv). Dan word die Ou Testament ' $n$ verslag van ' $n$ klein volkie wat te midde van verdrukking deur die groot nasies iets laat blyk het van die stryd ter wille van die Ryk van Geregtigheid en Jesus word 'n navolgingswaardige voorbeeld binne die konteks van hierdie selfde stryd. "Prime image of a Christian style of life is the servant or man-forothers image of Jesus". Ek glo nie dat dit nodig is dat ek hier beskrywe met watter vindingrykheid Rauschenbusch, Bonhoeffer, Tillich, Bultmann, Winter, Van Buren, Cox, Pannenberg, Mottmann en Schaull hierdie tema in verskillende rigtings uitwerk nie. Dit het ek in genoemde artikels meer as een keer gedoen. Een motief wat veral by Pannenberg, Moltmann en Schaull 'n belangrike rol speel, is die eksodus-motief: God is die God van die uittog, van die geskiedenis, dit wil sê van gedurige verandering 
wat oproep tot nuwe eksodusse uit die bestaande orde en strukture. Net wanneer 'n struktuur blywend word, word dit 'n onderdrukkende "establishment". Deur gedurige verandering te weeg te bring, word ons hieruit verlos en "belewe ons die heil binne hierdie aardse lewe, binne die gesigseinder van hierdie aarde ... want die ryk van God is 'n baie konkrete werklikheid van reg en liefde onder die mense en dra beslis ' $n$ politieke karakter" (Pannenberg). Vir Schaull beteken hierdie verandering politieke revolusie. Hy stel dat die voortdurende revolusie God se humaniserende arbeid in en met ons geskiedenis is. Staatkundige revolusie is die skerp kant van God se humaniserende werksaamheid in die geskiedenis. Marx was reg dat slegs gewelddadige revolusie sosiale verandering kan meebring. Hierby moet die Christen aansluit maar dan net vir voortdurende revolusie en versoening deur onderhandeling pleit.

B (e) Aansluitend hierby wil ons op 'n paar figure wys na wie ons nog nie voorheen gewys het nie:

(i) Die eerste is Tracy se "Blessed rage for order" waarop ons al vroeër gewys het. In sy Godsleer vind hy bv eerstens dat die Bybelse uitspraak dat God liefde is, slegs "a mere metaphor", "a mere symbol", "a useful antropomorphism" is. Net soos Moltmann-hulle, vind hy dat God se wese eerder dié van gedurige verandering is. In aansluiting by die Engels-Amerikaanse spraakgebruik stel hy: "God is dipolar". Dit beteken dat God se wese in 'n gedurige proses van self-skeppende verandering is, net soos die persoon van die mens ook met die verloop van tyd verander. God bestaan slegs in relasie met ander wesens en verander namate ons dade plaasvind en Hom beïnvloed. Só moet ons vandag die Bybelse begrip van die lewende God interpreteer en aan die moderne mens aanbied.

(ii) Eberhard Jüngel in sy boek "The Doctrine of Trinity". "God's Being Is in Becoming" (Duits 1966, Engels 1976 Eerdmans, Grand Rapids) kritiseer wel die "dipolar nature of God" in die Amerikaanse proses-teologie, maar kan ook nie Gollwitzer se stelling aanvaar dat God onafhanklik "in en vir Homself" bestaan en dan van daaruit "vir ons" daar is nie. Dit hou in dat God wesenlik onhistories en nie-in-verbandstaande is nie. Wie korrek oor God wil praat, moet besef dat God se wese "essentially relational" is soos blyk uit "Gods self-relatedness in his being as Father, as Son and as Holy Spirit" $(18,106)$. Jüngel beskryf wesenlike historisiteit van God se Trinitariese bestaanswese as: "God's being is in becoming". Dit bring ook mee dat God nie as 'n statiese mitologiese of metafisiese syn gesien sal word wat byvoorbeeld 
nie kan ly nie. God lê nie sy Godheid af deur te ly nie, maar is juis die werklik lewende God juis omdat Hy ly. Hierdie gedagtes werk Jüngel in sy nuutste boek “Gott als Geheimnis der Welt" (Mohr, Tübingen 1977) nader uit.

(iii) Hans Küng (onder andere skrywer van die groot boek “Die Kirche") sluit in sy boek "On Being a Christian" (Engelse vertaling Collins, London 1977) ook in sy dogmatiese denke nou by die Nuwe Teologie aan. Hy is oortuig van "the inability of modern man to respond to supernatural religion". Die spreuk: God het mens geword sodat ons kinders van God kan word, is vir die moderne mens volkome onverstaanbaar. Hy wil nie God of 'n Godskind word nie. "Our problem today is not the deification but the humanisation of man" $(21,442)$. Om Christen te wees beteken vir Küng "to be radically human", 'n basis wat ook die onware, niegoeie, lelike en onmenslike kan dra $(21,602)$. Jesus Christus is in hierdie strewe slegs ons voorbeeld, ons model wat ons moet navolg $(21,552)$. Navolg beteken "walking behind him, going our own way in the light of his directions" $(21,545)$.

(iv) Hier het weer eens iets van die normatiewe karakter van die bevryde, mondige moderne mens na vore gekom. Dit word onder andere sterk onderstreep in die boek $A$ Christian Declaration of Human Rights (uitgegee deur Allen O Miller, Eerdmans, Grand Rapids 1977). Dit is 'n positiewe reaksie op Jürgen Moltmann se The Theological Basis of Human Rights and of the Liberation of the man Rights. Moltmann stel drie dinge voorop:

(a) Christelike teologie is teologie van bevryding omdat dit Jesus Christus sien as die bevryder in die algemeenste sin van die woord.

(b) Die teologie van bevryding is die teologie van die mens, want elke mens is geskape na die beeld van God.

(c) Die teologie van bevryding is die teologie van die toekoms, want die koninkryk van die Seun van die Mens is die toekoms van die mens.

Die genoemde Declaration wil nou 'n teologie opbou wat omgesit kan word in 'n Christelike lewensstyl wat alle grense (wat onderdruk) uitwis. (Sien verder ook werk no 4 ).

(v) Moltmann sluit natuurlik nou aan by die groot Rooms-Katolieke teoloog, Johann B Metz oor wie daar in Afrikaans nog heel weinig geskryf is, mi mede ook daardeur dat hy in die moeilike filosofiese taal van Adorno en Habermas skryf. Sy 
boeke Zur Theologie der Welt (Kaiser, München 1968) en Kirche im Prozesz der Aufklärung (saam met Moltmann en Oelmüller) is bekend. Ek verwys en behandel hier egter 'n tipiese studie van Metz, Redemption and Emancipation (in Cross Currents, Vol XXVI, No 3, Fall 1977, p 321-336). Vir Metz is die verliging (die Aufklärung) wat in die 18e eeu duidelike historiese gestalte begin kry het, van beslissende belang. Dit is die "vryheidsgeskiedenis van die nuwe tyd". "I understand emancipation as a kind of epoch-constituting catchword for our contemporary experience of the world. It is a universal, almost historico-philosophical category for characterizing that Modern World with its processes of liberation and enlightment, within whole relationships (and not merely under whose conditions!) we must seek to articulate and resume responsibility for the christian message of redemption" $(29,322)$. Verligting of emansipasie "is the basic category of modern history of freedom" en hou in "the disappearance of any connotation of paternalistic condescension and the emergence of autonomy in the act of emancipation, the self-liberation of human groups and classes" $(29,322)$. "Het is onze roeping om in vryheid en redelijke verantwoordelikheid ons lot te bepalen. Dat betekent tegelijk, dat alle gezag zijn sokrale karakter ontnomen wordt" $(47,116-117)$. Die teologiese program van Metz is om sonder "to be compromised by theological half-measures" $(29,323)$ (a) "the liberating redemption in and through Jesus Christ" en (b) "the emancipatory-revolutionary-critical selfliberation of man" $(29,324)$, volledig, sonder kompromis met mekaar te integreer. Ons mag nooit in die slaggat val deur "simply subordinating the logos of redemption to the logos of emancipatory reason" of andersom nie $(29,324)$. Daarom moet ons (sê Metz) "in my opinion speak of soteriology as a political theology of redemption" $(29,328)$. Dit kan gebeur wanneer die Christelike boodskap van bevryding dialekties-krities teenoor die verligtingsgeskiedenis die mens se self-bevryding gestel word om te verhoed dat die moderne vryheidsgeskiedenisse nie stol én tot nuwe onderdrukkende strukture verstar en gesakraliseer word nie. Die manier waarop dit gebeur, is om die revolusionêre herinnering (Metz noem dit "subversive memory") van die lyding, dood en opstanding van Jesus Christus deur oorvertelling ("narrative") die bevryding lewend en vloeibaar te hou, "to permanently actualize it anew" $(29,333)$. Hierdie oorvertelling "seeks ... narratively to keep alive and argumentatively to defend the christian memory of redemption as a subver- 
sive-liberating memory of redeemed freedom among the systems of our so-called emancipated world" $(29,334)$.

Ons wys net daarop dat Metz nie net op Reformatoriese teoloë soos Moltmann groot invloed het nie, maar via sy studente en oudstudente ook ten opsigte van die Rooms Katolieke teoloë en kerk.

(vi) Toe Moltmann onlangs ons land besoek het, het hy 'n lesing gehou oor Die Bevryding van die Onderdrukker. Die onderdrukker (en die blankes in SA is by uitstek die voorbeelde daarvan) moet van drie dinge bevry word: Kapitalisme, Rassisme en Seksisme. Ek laat die eerste twee daar en sê iets baie kortliks oor Seksisme waaroor ek in die laaste tyd 'n taamlike hoeveelheid materiaal by die Merensky Biblioteek versamel het. Uit die omvattende literatuur verwys ek hier na die mededelings in twee artikels in Vox Theologica (Jrg 45, $\mathrm{nr} 4$, 1975) naamlik Trudi Klijn, Amerikaanse Vrouwen en de Theologie en Trudy van Asperen, Interview met Maria de Groot. Hieruit blyk dat die meer radikale teologinne in hulle stryd teen seksisme die fout met die Christendom en die Westerse kultuur vind in die bron van albei naamlik in die Bybel én in die interpretasie van die Bybel en die dogma, teologie, etiek en liturgie. Die fout is dat die Bybel geskryf en geïnterpreteer is deur diegene wat die mag deur die eeue in die hande het, naamlik blanke mans $(52,224)$. Daarom sal die Bybel, (wat "een vreselijke patriar-haal boek" genoem word) $(52,222)$ kerk en dogma die uitbuiting en onderdrukking van die arbeiders, swartes, gekolonialiseerdes en vroue noodwendig tot gevolg hê $(19,200)$. Daar moet 'n nuwe interpretasie van die Bybel, die kerk, die dogma, die kultuur, arbeidsverhoudings en die liturgie plaasvind, sodat daar 'n nuwe kerk- en kultuurpatroon kan ontstaan wat aan almal gelykheid toebedeel $(29,200$ en $52,226-227)$. In die ou godsdienste (bv in die Kanaänitiese godsdienste van Baal en Astarte) was daar 'n fyn balans tussen die vroulike en manlike dws tussen liggaam en siel, gevoel en rede, natuur en abstrakte gees, aarde en hemel ens. Die fout het gekom toe die blanke manlike Bybelskrywers hierteenoor die patriarchale, alleen-heerser Jahwe gestel het én in plaas van die Kanaänitiese natuurfeeste (waarin dood en opstanding in 'n organiese verband met mekaar gestaan het), historiese gebeurtenisse en die patroon verdoemenis-verlossing gaan stel het $(19,202)$. Hierteenoor wil die feministiese teologie God nie sien as 'n "Hy" nie, maar as 'n "di-polar process". Die tot-objek-maak van mense waarvan seksisme 'n oermodel is, word gesien as die sondeval van die mens. 
Erfsonde word gesien as die kontinuering van hierdie model dws van die sosiale en kulturele onderdrukking van mense omdat hulle anders is (dws vroue, swartes, jongmense). Opstanding en heil word gesien as die bevryding van hierdie paternalistiese struktuur en die terugwinning van 'n eie, gelyke en gelykwaardige identiteit van die onderdruktes $(19,201-202)$.

Binne hierdie konteks word ook teen die huidige liturgiese patroon beswaar gemaak waar die dominee op paternalistiese wyse die mense toespreek. Die nuwe patroon moet nie prediking wees nie, maar dialoog, gesprek $(52,226)$. Op gelyke wyse moet sending met ontwikkelingshulp en liefdadigheid deur aksie om geregtigheid vervang word $(52,226)$.

C (a) Natuurlik is nie alle dogmatiese werke (en veral nie die handboeke nie) resloos Nuwe Teologie, Teologie van die herinterpretasie van die Bybel en Bevryding nie. Sommige, soos Louis Berkhof se Systematic Theology (1ste druk 1939, 9e druk 1974, Cox and Wyman, London) gee wel aandag aan die rigting van Barthhulle, maar interpreteer die tradisionele leerstukke op die tradisionele Calvinistiese wyse. Daar het ook onlangs 'n splinternuwe herdruk van Herman Bavinck se Gereformeerde Dogmatiek verskyn omdat sommige Gereformeerdes gevoel het dat die nuwere handboeke te modernisties is.

C (b) Maar in meeste handboeke is daar tog in ' $n$ meerdere of mindere mate die invloed van die Nuwe Teologie te bespeur. So tree Helmut Thielicke in sy dogmatiek (waarvan die Engelse vertaling van die tweede deel pas by Eerdmans Grand Rapids verskyn het as "The Evangelical Faith, Vol II: The Doctrine of God and Christ") wel in lewendige diskussie met die hedendaagse teologiese denke, maar wesenlik bly sy posisie konserwatief Lutheraans. Daarteenoor hou Wolfhart Pannenberg byvoorbeeld in The Apostles' Creed in the Light of Today's Questions (Duits 1972, 3e druk in Engels, SCM Press London 1976) wel nog basies vas aan die Apostolicum-artikels, maar sy interpretasie laat die moderne gesekulariseerde mens se lewens- en wêreldbeskouing en vrae tog sterk meespreek. Dogmatiek moet volgens hom in drie fases verloop: Eerstens die vasstelling van "the original meaning of the formulations" in hulle ou, historiese konteks. Tweedens: Hoe sien die artikels daar uit "in the light of today's critical biblical scholarship" en derdens die moontlike betekenis van die artikels "for the Christian today in the context of the problems and convictions of the present understanding of reality" $(39, \mathrm{vii})$. Tyd ontbreek om aan te toon hoe Pannenberg dié program realiseer. 
$C$ (c) Ook die groot moderne dogmatiek-handboek uit die Hervormde Kerk, Nederland, dr H Berkhof se Christelijk geloof (Callenbach, Nijkerk 1973) laat die herinterpretasie van die Skrif in die lig van moderne probleme én die moderne mens en bevrydingstendens sterk meespreek. Hy realiseer veral die programpunt "om naar buiten het Evangelie zo verstaanbaar mogelijk te vertolken" $(6, x v)$. Daar moet "met betere hermeneutische kijkers gewerkt word, waardoor de mensen om ons heen het Woord Gods weer midden in hun eigen leven te horen krijgen". Soos in die Bybelse tyd, sal dit wat "in de leef- en denkvormen van hun situatie" aan hulle gegee is, "naar volgende geslachten toe moeten worden doorvertaald in hun situaties" $(6,81)$. Die tyd ontbreek ook hier om aan te toon hoedat hierdie program binne die bestek van 564 bladsye uitgewerk word. Ons stip slegs 'n paar punte aan van hoe genoemde moderne perspektiewe meespreek:

In sy Godsleer kom Berkhof baie naby aan die genoemde siening van God as "dipolar" in die Amerikaanse prosesteologie en die eweneens genoemde wesenlike "historicality" van God van Jüngel. Volgens Berkhof behoort "de veranderlykheid tot de omgang van God met de wêreld", want toe God geskep het en toe Christus gekom het, het God telkens verander.

$\mathrm{Hy}$ vind die formulering van die NGB art 1 "Abstract en steriel" $(6,114)$ en wil die Triniteitsleer sien as "de samenvattende beschrijving van het verbondsgebeuren". God is nie "één wezen in de eeuwigheid", maar "één geschiedenis in de tyd". Triniteit dui die wyse aan waarop God "zijn leven in de tijd uitbreidt en voortzet om er mensen deel aan te geven" (6,348-350).

God het 'n geskiedenis met dié mens begin, "God is de God van ontmoeting en verbond" en die mens is "deelgenoot van de ontmoeting en partner van God in het verbond". Hierdie mens is vry, want "vryheid is de existentiaal van het mens-zijn" $(6,193$ vv) en as sodanig is hy "medeschepper, medeonderhouer, mederegeerder" en "zaakwaarnemer Gods" (6 224). Alles in hierdie "wordende wêreld" is op vernuwing gerig ( 6,473 v en $521 \mathrm{vv})$, op die koninkryk van God "als volle verwerkelijking van het menszijn door gemeenschap met God" $(6,173)$.

In hierdie konteks is Jesus "de mens, de voleindigde verbondsmens, de Nieuwe Mens" $(6,302)$ want sy Seunskap hou dit in, is uitdrukking van "de nieuwe verbondsrelasie". Maar "in de mens wil God ook de wereld vernieuwen" en vir die praktiese uitvoering daarvan in die derde wêreld kan ons goeie lesse uit die Franse Revolusie leer $(6,521)$. Hoofwoorde by Berkhof is telkens: Verbond, Geskiedenis, Verandering, Vryheid, Vernuwing. 
C (d) Een van die bruikbaarste moderne dogmatiek-handboeke is Heinrich Ott (die opvolger van Barth in Basel) se Die Antwort des Glaubens (Kreuz Verlag, Berlin 1973). Hy het dit geskryf in medewerking met talle bekendes soos Otte, Uwe Gerber en Jan Veen hof en die boek volg 'n vaste patroon. Eers word ten opsigte van elkeen van die 50 behandelde leerstukke die vraag ontvou; dit beteken dat al die wesenlike sake wat in die vraag (byvoorbeeld ivm die skepping) ter sprake is, noukeurig geformuleer word. Daarná word 'n noukeurige oorsig van byna alle relevante leermeninge in die verlede gegee en laastens kry ons 'n poging tot ' $n$ antwoord van wat dié leerstuk aktueel vir die moderne mens te sê het.

Laat ons as voorbeeld neem die behandeling van die twee-natureleer by Ott $(38,249 \mathrm{vv})$. Nadat stappe één en twéé voltooi is, word Chalcedon se tweenatureleer nuut geïnterpreteer. Die tradisionele tweenatureleer is mitologies, "Göttergeschichlich" $(6,255)$. Ons kan sy goddelike natuur verklaar as die deurligting van sy menslike persoonlikheid deur 'n bo-aardse kwaliteit. So ontkom ons aan mitologie, maar één wesenlike aspek gaan verlore naamlik dat Jesus die spreker van God se taal was. Die sogenaamde goddelike natuur wil ook dít uitdruk. Die menslike natuur beteken dat Hy as mens "auch der Höhrer Gottes" was, wat beteken dat ek "persönlich gegenwärtig zugesprochen wird, und zwar so, dass ich mich vor dessen Sprecher persönlich zu verantworten habe". Daarom moet die tweenatureleer nie massief-ontologies gesien word nie, maar personalisties. Dan dui die twee natureleer aan: "So ist Gott im Leben jedes einzelnen Menschen in verborgener und personhafter Weise gegewärtig $(6,257)$.

Dit beteken: God wag op die mens, dit wil sê verwag van hom iets; maar as wagtende is $\mathrm{Hy}$ alreeds teenwoordig ("gegenwärtig"). Hierdie teenwoordigheid van God beteken dat hy met die mens solidêr is $(6,258)$. "So ist Gott kraft des Ereignisses der Menschwerdung in das Leben jedes Menschen eingesenkt". "Dieses Ineinandersein von göttlicher und menschlicher Wirklichkeit ist der Sinn einer personal gedeuteten Zweinaturenlehre" $(6,258)$.

D. Ek sou nog graag wou wys op die tendens in baie dogmatiese werke om teenoor Barth se metodiese fundering van die openbaring in God (wat loodreg van bo inslaan en waarop die mens wat net in die geloof sinvol kan antwoord), 'n algemener dogmatiese kennisleer op te stel (wat metodies en formeel by die algemene wetenskapsleer aansluit en inhoudelik by die algemene godsdiens- en skeppingsstrukture). Dit word byvoorbeeld in H M Kuitert se boek, Wat heet geloven?, structuur en herkomst van de christelijke geloofsuitspraken, 
Baarn 1977 gedoen. Ek sou graag ook nog verder oor Kuitert, Wiesenga, Pohlman, Buri, Grass, Rodding, Joest, Kreck, Macquarrie en ander se dogmatiese werke wou praat, maar dit moet ongelukkig tot 'n volgende keer wag.

\section{AANGEHAALDE WERKE}

(Nota: In die artikel haal ons op dié metode aan dat die eerste syfer die boeknommer soos in die lys aangegee, aandui en die tweede syfer die bladsy. Só byvoorbeeld sal 7,335 beteken: Boek no 7, naamlik Louis Berkhof, bl 335).

1. A J Ayer, Language, Truth and Ligic, New York (sj).

2. James Barr, The Semantics of Biblical Language, Oxford University Press 1961.

3. James Barr, Biblical Words for our time, 1962.

4. Jörg Bauer ea, Zum Thema Menschenrechte? Calwer, Verlag, Stuttgart 1977.

5. John C Bennett, The Radical Imperative: From Theology to Social Ethics, Westminister Press 1975.

6. H Berkhof, Christelijk Geloof, Callenbach, Nijkerk 1973.

7. Louis Berkhof, Systematic Theology, 9e druk Cox and Wyman, London 1974.

8. Bruce C Birch and Larry L Rasmussen, Bible and Ethics in Christian Life, Augsburg Publishing House, Mineapolis 1976.

9. Jean Carmignac, Recherches sur le 'Notre Pére', Ed Letouzey et Ené, Paris 1969.

10. Wallace L Chafe, Meaning and Structure of Language, Univ. of Chicago Press, Chicago 1970.

11. Noam Chomsky, Syntactic Structures, Mouton, The Hague 1957.

12. B J Engelbrecht, Hedendaagse Krisispunte in die Teologie (in: Hervormde Teologiese Studies, Jrg 23, Afl 1, bl 5-23)

13. B J Engelbrecht, Die antwoord van die kerk ten opsigte van sekularisasie (in: Hervormde Teologiese Studies, Jrg 24, Afl 3, bl 142-154).

14. B I Engelbrecht, Die teologie van die hoop en die teologie van die revolusie (in: Die Bybel en die moderne mens, SA Akademie 1974, bl 39-51).

15. J Friedrich, Gott im Brüder, Calwer Verlag, Stuttgart 1977.

16. Stanley Hauerwas, Character of Christian Life, Trinity Univ Press, San Antonio 1975.

17. Anders Jeffner, Kriterien Christlicher Glaubenslehre, Uppsala 1976.

18. Eberhard Jüngel, The Doctrine of Trinity: God's Being is in Becoming, Eerdmans, Grand Rapids 1976.

19. Trudi Klein, Amerikaanse vrouwen en de Theologie (in: Vox Theologica, 1975, No 4, p 194-204).

20. John Knox, The Humanity and Divinity of Christ, Cambridge Univ Press, sj.

21. Hans Küng, On Being a Christian, Collins, London 1977.

22. H M Kuitert, Wat heet geloven? structuur en herkomst van de christelijke geloofsuitspraken, Baarn 1977.

23. Robert $E$. Longacre et al, The deep and surface grammar and interclausal relations (in: Foundations of Language, no 7, p 70-118).

24. I A Loader, Gedagtes oor gekontroleerde eksegese (in: Hervormde Teologiese Studies, Jrg 34, Afl 1 en 2, Pretoria 1978).

25. J P Louw, Semantiek van die Nuwe Testamentiese Grieks, Pretoria 1977.

26. Earl $R$ MacCormac, Metaphor and Myth in Science and Religion, Duke Univ Press, NC 1976.

27. J B Metz, Zur Theologie der Welt, Kaiser Verlag, München 1968.

28. J B Metz en Moltmann en Oelmüller, Die Kirche im Prozesz der Aufklärung.

29. Johann B Metz, Redemption and Emancipation (in: Cross Currents, Vol XXVI, No 3, Fall 1977, p 321-336).

30. Allen $O$ Miller (ed), A Christian Declaration on Human Rights, Eerdmans, Grand Rapids 1977. 
31. Eugene A Nida, Toward a Science of Translation, E J Brill, Leiden 1964.

32. Eugene $A$ Nida and Charles $R$ Taber, Theory and Practice of translation, E J Brill, Leiden 1969.

33. Eugene A Nida, Linguistics and Translators (in: Technical Papers for the Bible Translator, Vol 23, No 2, April 1972, p 225-233).

34. Eugene A Nida, Linguistic Theories and Bible Translating (in: Technical Papers for The Bible Translator, Vol 23, No 3, July 1972, p 301-308).

35. Eugene $A$ Nida, Communication and Translation (in the same as above, $\mathrm{p}$ 309316).

36. Eugene A Nida, Varieties of Language (in the same as above, $\mathrm{p}$ 316-322).

37. Eugene A Nida, Language and Psychology (in the same as above, Vol 26, No 3, July 1975, p 308-312).

38. Heinrich Ott, Die Antwort des Glaubens: Systematische Theologie in 50 Artikeln, Kreuz Verlag, Berlin 1973.

39. Wolfhart Pannenberg, The Apostles Creed in the Light of Today's Questions, SCM Press, London 1972.

40. Kenneth L Pike, Grammemic Theory (in: General Linguistics, No 2, p 35-41).

41. F A Ponelis, Grondtrekke van die Afrikaanse sintaksis, Van Schaik, Pretoria, 1968.

42. Ian T Ramsay, Religious Language. An Empirical Placing of Theological Phrases, New York 1963.

43. Ian T Ramsay, Models and Mystery, London 1964.

44. Edward Schillebeekckx, Jesus, het verhaal van de Levende, Nellissen, Bloemendaal 1974.

45. Edward Schillebeekckx, Geregtigheid en liefde. Genade en bevrijding, Nellissen, Bloemendaal 1977.

46. I Sperna Weiland, Orientatie, Wereldvenster, Baarn 1966.

47. I Sperna Weiland, Voortgezette Orientatie, 3e druk, Wereldvenster, Baarn 1971.

48. $K$ Arvid Tängberg, Linguistics and theology (in: Technical Papers for the Bible Translator, Vol 24, No 3, July, 1973, p 301-310).

40. Helmut Thielicke, The Evangelical Faith (Vol II): The Doctrine of God and of Christ.

50. David Tracy, Blessed Rage for Order: The new pluralism in theology, The Seabury Press, NY 1975.

51. A $G$ van Aarde, Moderne semantiek en formele homilitiek (in: Hervormde Teologiese Studies, Jrg 34, Afl 1 en 2, Pretoria 1978).

52. Trudy van Asperen, Interview met Maria de Groot (in: Vox Theologica, 1975, No 4, bl 221-227).

53. Paul van Buren, The Secular Meaning of the Gospel based on an Analysis of its Language, 1963.

54. M C J van Rensburg, Die struktuur van die sin in Afrikaans, Pretoria 1971.

55. John T Waterman, Perspectives in Linguistics, Univ of Chicago Press, Chicago 1963.

Addendum:

56. Ná die opstel van dié referaat het daar 'n ander boek wat oor dieselfde onderwerp as boek nommer 17 (Jeffner) handel en mi nog eksakter te werk gaan in sy analise van die aard, geldigheid en struktuur van hedendaagse denke in die Sistematiese Teologie onder my aandag gekom. Dié boek is:

Koloman $N$ Micskey, Axiom-Syntax de evangelisch-dogmatischen Denkens. Struktur-analysen des Denkprozesses und des Wahrheitsbegriffs in dem Wissenschafts-theorien zeitgenössischer systematischer Theologen, Vandenhoeck en Ruprecht, Göttingen 1976. 